\begin{tabular}{l} 
JOURNAL OF EMPOWERMENT \\
Vol. 1, No. 2, December 2017, h. 87-102 \\
ISSN 2580-0620 (Print) \\
ISSN 2597-9809 (online) \\
Available Online at https://jurnal.unsur.ac.id/index.php/JE \\
\hline \hline
\end{tabular}

\title{
FOCUS GROUP DISCUSSION MENGENAI PEMAHAMAN PERUBAHAN ATURAN HUKUM INDIKASI GEOGRAFIS BAGI MASYARAKAT PELESTARI PADI PANDANWANGI CIANJUR (MP3C) SEBAGAI PEMEGANG HAK INDIKASI GEOGRAFIS TERDAFTAR
}

\author{
M. Rendi Aridhayandi \\ Universitas Katolik Parahyangan Bandung \\ E-mail: suryakancanarendi@gmail.com
}

Masuk : September $2017 \quad$ Penerimaan : Oktober 2017

Publikasi : Desember 2017

\begin{abstract}
ABSTRAK
Era perdagangan global, sejalan dengan konvensi internasional yang telah diratifikasi Indonesia, peranan Merek dan Indikasi Geografis menjadi sangat penting terutama dalam menjaga persaingan usaha yang sehat, berkeadilan, pelindungan konsumen, serta pelindungan Usaha Mikro, Kecil, dan Menengah dan industri dalam negeri. Undang-Undang Nomor 15 Tahun 2001 tentang Merek masih terdapat kekurangan dan belum dapat menampung perkembangan kebutuhan masyarakat di bidang Merek dan Indikasi Geografis serta belum cukup menjamin pelindungan potensi ekonomi lokal dan nasional sehingga perlu diganti. Maka hadir Undang-Undang Nomor 20 Tahun 2016 tentang Merek dan Indikasi Geografis yang lebih konfrehensif pengaturannya. Upaya Pemerintah Daerah Kabupaten Cianjur melalui Masyarakat Pelestari Padi Pandanwangi Cianjur (MP3C) Di tahun 2015 Beras Pandanwangi Cianjur telah terdaftar Indikasi Geografis (IG) tanggal 16 Oktober 2015 dengan nomor permohonan: IG. 00.2014 .000011 dan nomor pendaftaran ID G 000000034. Dengan demikian, dianggap perlu untuk melakukan focus group discution ke (MP3C) sebagai pemegang hak Indikasi Geografis Terdaftar.
\end{abstract}

Kata Kunci: Indikasi Geografis, Focus Group Discution, Masyarakat Pelestari Padi Pandanwangi Cianjur (MP3C).

\begin{abstract}
The era of global trade, in line with the international conventions that have been ratified by Indonesia, the role of the brand and the geographical indication becomes very important especially in maintaining a healthy business competition, fairness, shield cover consumers, as well as shield cover micro, small, and medium enterprises and industries in the country. Act No. 15 of 2001 Year Brand still contained flaws and yet accommodates the development needs of the community in the field of Geographical Indications as well as brand and not enough guarantee shield cover local and national economic potential so as to need to be replaced. Then the present Act No. 20 Year 2016 about brands and Geographic Indications konfrehensif setting. The efforts of local governments through communities Cianjur Of Cianjur Pandanwangi Rice (MP3C) in year 2015 Pandanwangi Rice Cianjur registered geographical indications (IG) October 16, 2015 with a plea: IG. 00.2014.000011 and registration number ID G 000000034 . Thus, it was considered necessary to conduct a focus group to discution (MP3C) as the holder of the rights of a registered geographical indication.
\end{abstract}


Keywords: Geographical Indications, Focus Group Discution, Pandanwangi Rice Cianjur Conservationist Society (MP3C).

\section{A. PENDAHULUAN}

\section{Latar Belakang}

Keikutsertaan Indonesia meratifikasi Konvensi tentang Pembentukan Organisasi Perdagangan Dunia (World Trade Organization) yang mencakup pula persetujuan tentang Aspek-aspek Dagang dari Hak Kekayaan Intelektual/HKI (Trade Related Aspect of Intellectual Property Rights/TRIPs) sebagaimana telah disahkan dengan Undang-Undang Nomor 7 Tahun 1994 tentang Pengesahan Agreement Establishing the World Trade Organization (Persetujuan Pembentukan Organisasi Perdagangan Dunia), telah menuntut Indonesia untuk mematuhi dan melaksanakan isi dari perjanjian internasional tersebut. Ratifikasi dari peraturan tersebut mendorong keikutsertaan Indonesia dalam meratifikasi Paris Convention for the Protection of Industrial Property (Konvensi Paris) yang telah disahkan dengan Keputusan Presiden Nomor 15 Tahun 1997 dan Trademark Law Treaty (Traktat Hukum Merek) yang disahkan dengan Keputusan Presiden Nomor 17 Tahun 1997.1

Hal tersebut di atas menjadi alasan terbitnya Undang-Undang Nomor 20 Tahun 2016 tentang Merek dan Indikasi Geografis. Tentang Indikasi Geografis perlu diatur mengingat Indikasi Geografis merupakan potensi nasional yang dapat menjadi komoditas unggulan, baik dalam perdagangan domestic maupun internasional.

Anggapan bahwa meningkatnya kesejahteraan masyarakat yang

1 Penjelasan Umum Undang-Undang Nomor 20 Tahun 2016 tentang Merek dan Indikasi Geografis. memiliki potensi produk indikasi geografis telah menujukan bahwa indikasi geografis merupakan rezim yang patut untuk mendapat tempat dalam aturan TRIPs sebagai bagian dari HKI. ${ }^{2}$

Selanjutnya, Indikasi Geografis merupakan salah satu rezim Hak Kekayaan Intelektual yang paling dipengaruhi oleh nilai-nilai masyarakat setempat atau budaya kelompok masyarakat atau bangsa dalam suatu Negara. ${ }^{3}$

Sangat penting sekali memahami perkembangan pengaturan Indikasi Geografis. Di Indonesia, Indikasi Geografis masih merupakan aturan sisipan, yaitu bersama dengan pengaturan Merek. Pengaturan Indikasi Geografis mulai diatur dalam Undang-Undang Nomor 14 tahun 1997 tentang Merek. Selanjutnya, diubah dengan UndangUndang Nomor 15 Tahun 2001 tentang Merek, lalu diubah lagi dengan Undang-Undang Nomor 20 Tahun 2016 tentang Merek dan Indikasi Geografis. Selain UndangUndang terdapat Peraturan Pemerintah Republik Indonesia Nomor 51 Tahun 2007 Tentang Indikasi Geografis, sebagai pelaksanaan ketentuan Pasal 56 ayat (9) Undang-Undang Nomor 15 Tahun 2001 tentang Merek.

Berdasarkan hal tersebut di atas maka penulis melaksanakan pengabdian pada masyarakat

Rahmi Jened, (2015), Hukum Merek (Dalam Era Global \& Integrasi Ekonomi), Jakarta, Kencana, hlm. 254-255.

Jill McKeough, Andrew Stewart, Philip Griffith, (2004), Intellectual Property in Australia, edisi ke-3, Sdyney, Butterworths, hlm. 603-604.

Focus Group Discution Mengenai Pemahaman Perubahan Aturan Hukum Indikasi Geografis

Bagi Masyarakat Pelestari Padi Pandanwangi Cianjur (MP3C)

Sebagai Pemegang Hak Indikasi Geografis Terdaftar 


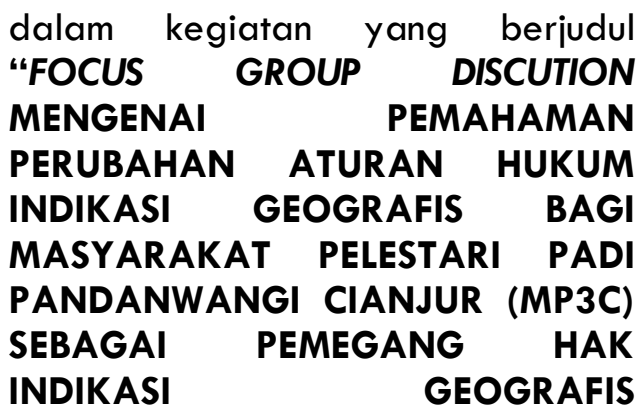

TERDAFTAR". Mensosialisasikan peraturan yang berkaitan dengan Indikasi Geografis di Masyarakat Pelestari Padi pandanwangi Cianjur (MP3C), oleh karena itu penulis hanya membatasi pada hal-hal sebagai berikut:

a. Materi apa saja yang disampaikan dalam kegiatan focus group discution mengenai pemahaman perubahan aturan hukum Indikasi Geografis bagi Masyarakat Pelestari Padi Pandanwangi Cianjur (MP3C) sebagai pemegang hak indikasi geografis terdaftar?

b. Bagaimanakah respon para Masyarakat Pelestari Padi Pandanwangi Cianjur (MP3C) terhadap kegiatan focus group discution mengenai pemahaman perubahan aturan hukum Indikasi Geografis?

\section{Lokasi Pengabdian}

Focus Group Discution ini dilaksanakan di Kantor Masyarakat Pelestari Padi Pandanwangi Cianjur (MP3C) pada Bulan September 2017.

\section{Peserta}

Peserta kegiatan tersebut dihadiri kurang lebih 5 (lima) orang perwakilan.

\section{B. METODE}

$\mathrm{Di}$ dalam penulisan artikel ini menggunakan metode pendekatan yuridis normatif, dengan spesifikasi penelitian yaitu deskriptif analisis. Lokasi pengabdian pada masyarakat ini dilakukan di Kabupaten Cianjur.

\section{HASIL/PEMBAHASAN}

1. Materi Focus Group Discution

Bung Karno (sebagai pembicara terakhir pada 1 Juni 1945) menyatakan: 1) Negara semua buat semua, bukan negara buat satu orang, bukan buat satu golongan, baik golongan bangsawan, maupun golongan yang kaya, tetapi semua buat semua; 2) Dasar pemikiran: Dasar Kebangsaan; Dasar Internasionalisme; Dasar Mufakat; Prinsip Kesejahteraan; Dasar Ketuhanan. ${ }^{4}$

Hal ini yang disebut lima dasar yang dikemukakan Bung Karno sebagai (Filosofische Grondslag) yaitu Pancasila.

Jika memperhatikan dasar pemikiran Bung Karno huruf $d$ tentang prinsip kesejahteraan, hal ini selaras dengan pembukaan Undang-Undang Dasar Negara Republik Indonesia Tahun 1945 (UUD NRI 1945), dalam alenia ke-4 (empat) Pembukaan UndangUndang Dasar Negara Kesatuan Republik Indonesia Tahun 1945 yang berbunyi: "...melindungi segenap bangsa Indonesia dan seluruh tumpah darah Indonesia dan untuk memajukan kesejahteraan umum...".

Makna Pembukaan UUD 1945 di atas, menegaskan tentang pentingnya menciptakan suatu kesejahteraan umum dalam negara (welfare state). Untuk memajukan kesejahteraan umum tersebut, mutlak dibutuhkan

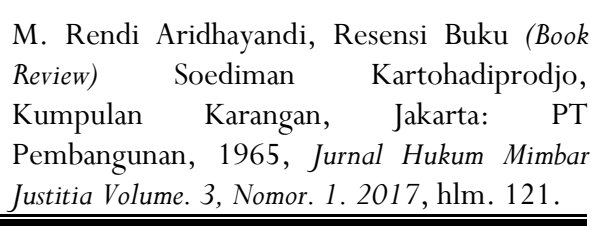

Focus Group Discution Mengenai Pemahaman Perubahan Aturan Hukum Indikasi Geografis

Bagi Masyarakat Pelestari Padi Pandanwangi Cianjur (MP3C)

Sebagai Pemegang Hak Indikasi Geografis Terdaftar 
sarana ketertiban sosial, yang merujuk pada upaya menciptakan aman, tertib dan damai, yang salah satunya melalui sarana hukum (terutama penegakan hukum). Hukum yang berfungsi imperatif sebagai sarana kontrol sosial diwujudkan dalam sanksi-sanksinya, yang berkolerasi antara penerapan hukum sebagai kebijakan hukum. ${ }^{5}$

Mewujudkan tata kehidupan Negara dan bangsa yang adil dan sejahtera, aman, tentram, dan tertib, serta menjamin kedudukan hukum yang sama bagi warga masyarakat merupakan suatu tujuan ideal setiap bangsa. 6

Tujuan yang hendak dicapai Negara Indonesia adalah terwujudnya masyarakat yang adil dan makmur baik spiritual maupun material berdasarkan Pancasila. 7

Negara hukum telah tergambar jelas dalam UUD 1945. Salah satu esensi Negara hukum adalah ditampilkannya peranan hukum secara mendasar sebagai titik sentral dalam kehidupan ketatanegaraan dan kemasyarakatan menuju kehidupan yang adil dan sejahtera. ${ }^{8}$

\footnotetext{
Henny Nuraeny, Penyuluhan Hukum Mengenai Undang-Undang Nomor 21 Tahun 2007 Tentang Pemberantasan Tindak Pidana Perdagangan Orang Bagi Guru Bimbingan Konseling Dan Siswa/Siswi SMK/SMA/MA Se-Kabupaten Cianjur, Journal Of Empowerment Volume. 1, Nomor. 1, 2017, hlm. 26.

6 Anita Kamilah dan M. Rendi Aridhayandi, Kajian Terhadap Penyelesaian Sengketa Pembagian Harta Warisan Atas Tanah Akibat Tidak Dilaksanakannya Wasiat Oleh Ahli Waris Dihubungkan Dengan Buku II Kitab Undang-Undang Hukum Perdata Tentang Benda (Van Zaken), Jurnal Wawasan Hukum Volume. 32, Nomor. 1, 2015, hlm. 23.

7 Lilik Mulyadi, (2007), Pembalikan Beban Pembuktian Tindak Pidana Korupsi, Alumni, Bandung, hlm. 64.

8 T. Subarsyah Sumadikara, (2010), Penegakan Hukum (Sebuah Pendekatan Politik Hukum dan
}

Berikut beberapa rumusan-rumusan keadilan:

a. Keadilan adalah kemauan yang bersifat tetap dan terus-menerus untuk memberikan kepada setiap orang apa yang semestinya untuknya (lustitia est constans et perpetua voluntas ius suum cuique tribuendi-Ulpianus).

b. Keadilan adalah suatu kebijakan politik yang aturan-aturannya menjadi dasar dari peraturan negara dan aturan-aturan ini merupakan ukuran tentang apa yang hak (Aristoteles). Menurut Arisoteles, orang harus mengendalikan diri dari pleonexia, yaitu memperoleh keuntungan bagi diri sendiri dengan cara merebut apa yang merupakan kepunyaan orang lain, atau menolak apa yang seharusnya diberikan kepada orang lain;

c. Keadilan adalah kebajikan yang memberikan hasil, bahwa setiap orang mendapat apa yang merupakan bagiannya". (Keadilan Justinian);

d. Setiap orang bebas untuk menentukan apa yang akan dilakukannya, asal ia tidak melanggar kebebasan yang sama dari orang lain. (Herbert Spencer);

e. Roscoe Pound melihat keadilan dalam hasil-hasil konkrit yang bisa diberikannya kepada masyarakat. Singkatnya social engineering yang semakin efektif;

f. Tidak ada arti lain bagi keadilan kecuali persamaan pribadi (Nelson);

g. Norma keadilan menentukan ruang lingkup dari kemerdekaan

Politik Kriminal), TT, Kencana Utama, hlm. 16. 
individual dalam mengejar kemakmuran individual, sehingga dengan demikian membatasi kemerdekaan individu di dalam batas-batas sesuai dengan kesejahteraan ummat manusia. (John Salmond);

h. Keadilan, buat saya adalah, suatu tertib sosial tertentu yang di bawah lindungannya usaha untuk mencari kebenaran bisa berkembang dengan subur. Keadilan saya karenanya adalah, keadilan kemerdekaan, keadilan perdamaian, keadilan demokrasi-keadilan toleransi. (Hans Kelsen).

i. John Rawls mengkonsepkan keadilan sebagai fairness, yang mengandung asas-asas. "bahwa orang-orang yang merdeka dan rasional yang berkehendak untuk mengembangkan kepentingan-kepentingannya hendaknya memperoleh suatu kedudukan yang sama pada saat akan memulainya dan itu merupakan syarat yang fundamental bagi mereka untuk memasuki perhimpunan yang mereka kehendaki. 9

Selanjutnya, dalam kehidupan ketatanegaraan dan kemasyarakatan menuju dan sejahtera. Merupakan kesejahteraan masyarakat yang sekaligus mencakup perlindungan masyarakat, jadi di dalam pengertian social politic, di dalamnya mencakup social welfare politic. ${ }^{10}$

9 Dwidja Priyatno dan M. Rendi Aridhayandi, Resensi Buku (Book Review) Satjipto RahardjoIlmu Hukum, Jurnal Hukum Mimbar Justitia Volume. 2 Nomor. 2. 2016, hlm. 884-885.

10 Trini Handayani, Pencegahan Permainan "Starter" Melalui Pendekatan Personal Safety Skill Pada Murid Sekolah Dasar, Journal Of
Welfare state telah diamanatkan dengan jelas dalam Pancasila dan UUD 1945, khususnya yang mengatur perekonomian dan hak warga negara, untuk melaksanakan konsep negara kesejahteraan, salah satunya adalah campur tangan pemerintah terhadap aspek kehidupan masyarakat yang berupa pengaturan dalam rangka menciptakan kesejahteraan masyarakat. ${ }^{11}$

Aktualisasi dari tujuan hukum dapat diciptakan oleh badan-badan yang berwenang menetapkan peraturan atau undang-undang yang diformulasikan dalam bentuk aturan hukum seperti undang-undang (UU). ${ }^{12}$ Hal ini berkaitan perlindungan hukum secara komprehensif dan konkret dari pemerintah. ${ }^{13}$

Peraturan atau undang-undang seringkali berganti sesuai kebutuhan dan perkembangan. Termasuk pengaturan terhadap Indikasi Geografis. Berikut perkembangan pengaturan Indikasi Geografis:

Empowerment, Volume. 1, Nomor. 1. Edisi Juni 2017, hlm. 66

11 Cucu Solihah, dan Aji Mulyana, Pembayaran Zakat dan Pajak di Negara Hukum Pancasila, Syiar Hukum, Volume. 15, Nomor. , 2017, hlm. 19.

12 Henny Nuraeny, (2011), Tindak Pidana Perdagangan Orang Kebijakan Hukum Pidana dan Pencegahannya, Jakarta, Sinar Grafika, hlm. 14-15.

13 Ahmad Hunaeni Zulkarnaen, Penyuluhan Tentang Tata Cara Membuat Peraturan Perusahaan Di PT. Pelangi Warna Kreasi Bandung, Journal Of Empowerment, Volume. 1, Nomor. 1, 2017-, hlm. 41.

Focus Group Discution Mengenai Pemahaman Perubahan Aturan Hukum Indikasi Geografis

Bagi Masyarakat Pelestari Padi Pandanwangi Cianjur (MP3C)

Sebagai Pemegang Hak Indikasi Geografis Terdaftar 
Tabel 1.1

Pengaturan Indikasi Geografis Menurut Undang-Undang Nomor 14 tahun 1997 tentang Merek

\begin{tabular}{|c|c|c|}
\hline No & Pasal & Isi Pasal \\
\hline 1 & $\begin{array}{l}\text { Pasal } \\
79 A\end{array}$ & 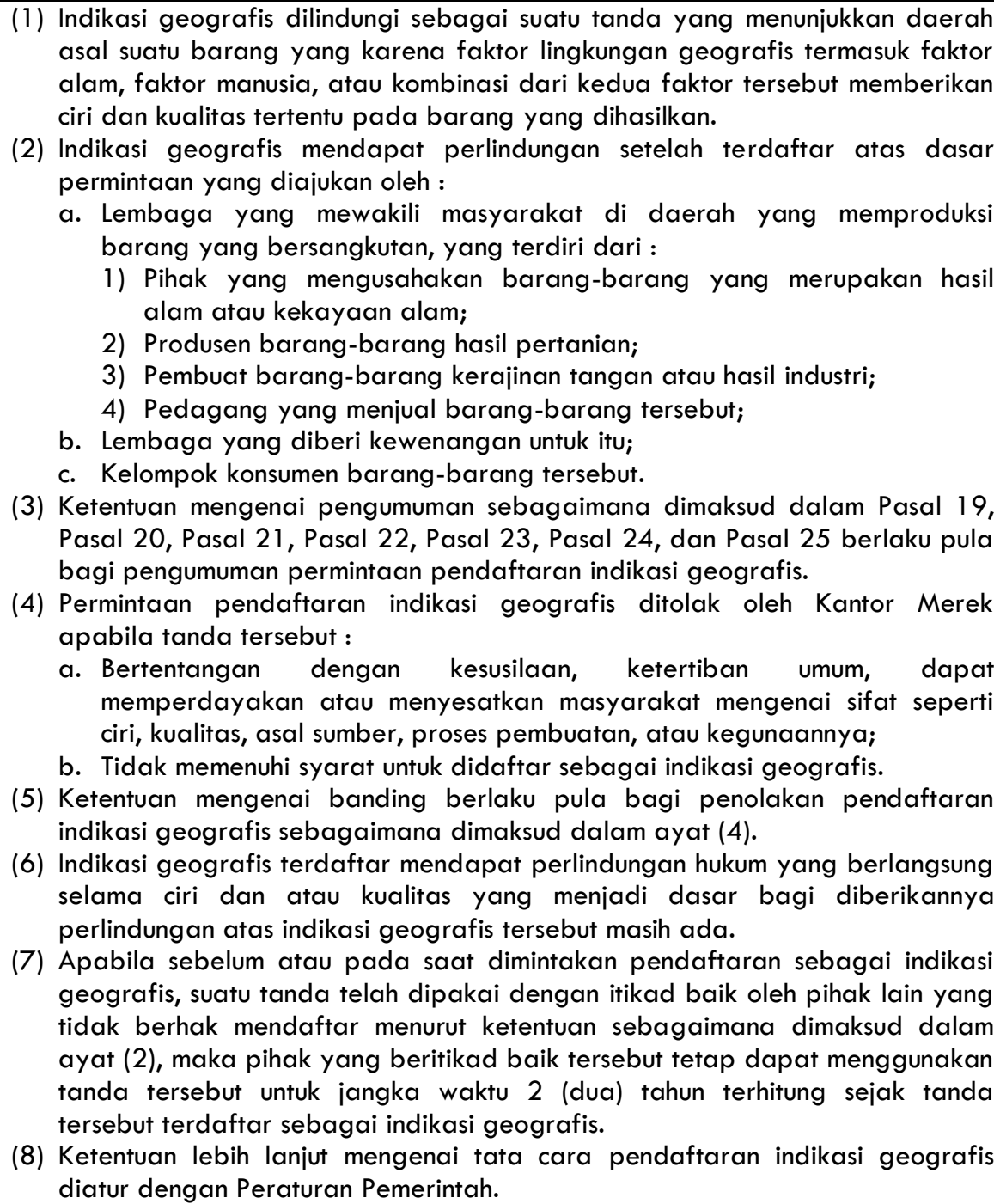 \\
\hline 2 & $\begin{array}{l}\text { Pasal } \\
79 B\end{array}$ & $\begin{array}{l}\text { (1) Pemegang hak atas indikasi geografis, dapat mengajukan gugatan terhadap } \\
\text { pemakai indikasi geografis secara tanpa hak, berupa permintaan ganti rugi } \\
\text { dan penghentian penggunaan serta pemusnahan etiket indikasi geografis } \\
\text { yang digunakan secara tidak sah tersebut. } \\
\text { (2) Untuk mencegah kerugian yang lebih besar pada pihak yang haknya } \\
\text { dilanggar, Hakim dapat memerintahkan pelanggar untuk menghentikan } \\
\text { kegiatan pembuatan, perbanyakan, serta memerintahkan pemusnahan etiket } \\
\text { indikasi geografis yang digunakan secara tidak sah tersebut. }\end{array}$ \\
\hline 3 & $\begin{array}{l}\text { Pasal } \\
79 \mathrm{C}\end{array}$ & $\begin{array}{l}\text { Ketentuan sebagaimana dimaksud dalam Pasal } 80 \text { berlaku pula dalam rangka } \\
\text { pelaksanaan hak atas indikasi geografis. }\end{array}$ \\
\hline 4 & $\begin{array}{l}\text { Pasal } \\
79 D\end{array}$ & $\begin{array}{l}\text { Indikasi asal dilindungi sebagai suatu tanda yang: } \\
\text { a. Memenuhi ketentuan Pasal 79A ayat (1), tetapi tidak didaftarkan; atau } \\
\text { b. Semata-mata menunjukkan asal suatu barang atau jasa. }\end{array}$ \\
\hline 5 & $\begin{array}{l}\text { Pasal } \\
79 E\end{array}$ & $\begin{array}{l}\text { Ketentuan sebagaimana dimaksud dalam Pasal 79B dan Pasal 79C berlaku } \\
\text { pula terhadap pemegang hak atas indikasi asal. }\end{array}$ \\
\hline
\end{tabular}


Tabel 1.2

Pengaturan Indikasi Geografis Menurut Undang-Undang Nomor 15 tahun 2001 tentang Merek

\begin{tabular}{|c|c|c|}
\hline No & Pasal & Isi Pasal \\
\hline 1 & $\begin{array}{c}\text { Pasal } \\
56\end{array}$ & 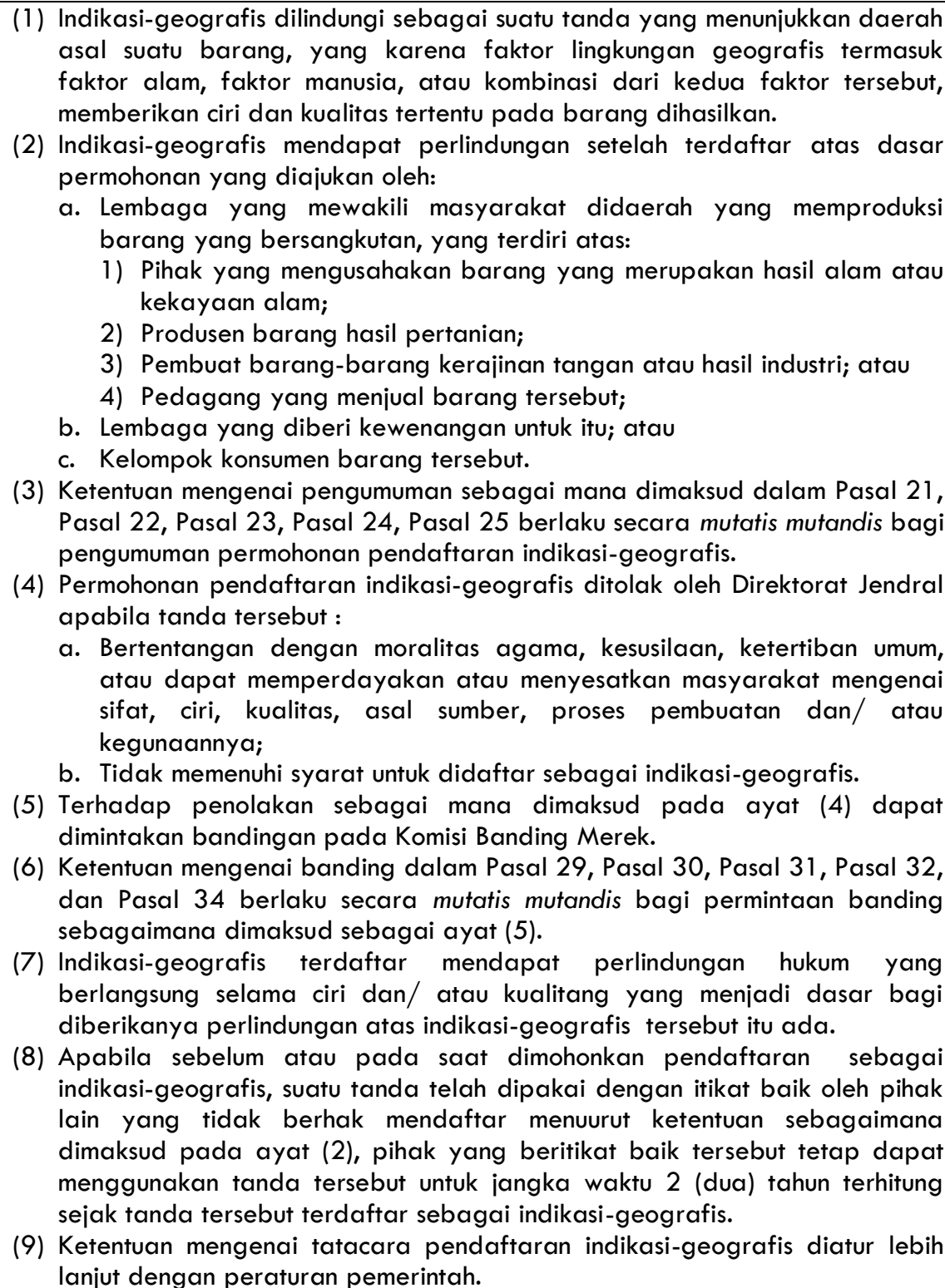 \\
\hline 2 & $\begin{array}{c}\text { Pasal } \\
57\end{array}$ & $\begin{array}{l}\text { (1) Pemegang hak atas indikasi geografis, dapat mengajukan gugatan } \\
\text { terhadap pemakai indikasi geografis secara tanpa hak, berupa permintaan } \\
\text { ganti rugi dan penghentian penggunaan serta pemusnahan etiket indikasi } \\
\text { geografis yang digunakan secara tidak sah tersebut. } \\
\text { (2) Untuk mencegah kerugian yang lebih besar pada pihak yang haknya } \\
\text { dilanggar, Hakim dapat memerintahkan pelanggar untuk menghentikan } \\
\text { kegiatan pembuatan, perbanyakan, serta memerintahkan pemusnahan } \\
\text { etiket indikasi geografis yang digunakan secara tidak sah tersebut. }\end{array}$ \\
\hline 3 & $\begin{array}{c}\text { Pasal } \\
58\end{array}$ & $\begin{array}{l}\text { Ketentuan mengenai penetapan sementara sebagai mana dimaksud dalam BAB } \\
\text { XII undang-undang ini berlaku secara mutatis mutandis terhadap pelaksanaan } \\
\text { hak atas indikasi geografis. }\end{array}$ \\
\hline 4 & $\begin{array}{c}\text { Pasal } \\
59\end{array}$ & $\begin{array}{l}\text { Indikasi-asal dilindungi sebagai suatu tanda yang: } \\
\text { a. Memenuhi ketentuan Pasal } 56 \text { ayat ( } 1 \text { ), tetapi tidak didaftarkan atau; } \\
\text { a. Semata-mata menunjukan asal suatu barang atau jasa. }\end{array}$ \\
\hline
\end{tabular}

Focus Group Discution Mengenai Pemahaman Perubahan Aturan Hukum Indikasi Geografis

Bagi Masyarakat Pelestari Padi Pandanwangi Cianjur (MP3C)

Sebagai Pemegang Hak Indikasi Geografis Terdaftar 


\begin{tabular}{|c|c|l|}
\hline 5 & $\begin{array}{c}\text { Pasal } \\
60\end{array}$ & $\begin{array}{l}\text { Ketentuan sebagaimana dimaksud dalam Pasal } 57 \text { dan Pasal } 58 \text { berlaku secara } \\
\text { mutatis mutandis terhadap pemegang hak atas indikasi-asal. }\end{array}$ \\
\hline
\end{tabular}

Tabel 1.3

Pengaturan Indikasi Geografis Menurut Undang-Undang Nomor 20 Tahun 2016 tentang Merek dan Indikasi Geografis

\begin{tabular}{|c|c|c|}
\hline No & Pasal & Isi Pasal \\
\hline 1 & \begin{tabular}{|c|} 
Pasal \\
53
\end{tabular} & $\begin{array}{l}\text { (1) Indikasi Geografis dilindungi setelah Indikasi Geografis didaftar oleh } \\
\text { Menteri. } \\
\text { (2) Untuk memperoleh pelindungan sebagaimana dimaksud pada ayat (1), } \\
\text { Pemohon Indikasi Geografis harus mengajukan Permohonan kepada } \\
\text { Menteri. } \\
\text { (3) Pemohon sebagaimana dimaksud pada ayat (2) merupakan: } \\
\text { a. Lembaga yang mewakili masyarakat di kawasan geografis tertentu } \\
\text { yang mengusahakan suatu barang dan/atau produk berupa: } \\
\text { 1. Sumber daya alam; } \\
\text { 2. Barang kerajinan tangan; atau } \\
\text { 3. Hasil industri. } \\
\text { b. Pemerintah daerah provinsi atau kabupaten/kota. } \\
\text { Ketentuan mengenai pengumuman, keberatan, sanggahan, dan penarikan } \\
\text { kembali sebagaimana dimaksud dalam Pasal } 14 \text { sampai dengan Pasal } 19 \\
\text { berlaku secara mutatis mutandis bagi Permohonan pendaftaran Indikasi } \\
\text { Geografis. }\end{array}$ \\
\hline 2 & $\begin{array}{c}\text { Pasal } \\
54\end{array}$ & $\begin{array}{l}\text { Permohonan yang diajukan oleh Pemohon yang bertempat tinggal atau } \\
\text { berkedudukan tetap di luar wilayah Negara Kesatuan Republik Indonesia } \\
\text { wajib diajukan melalui Kuasanya di Indonesia. } \\
\text { Permohonan sebagaimana dimaksud pada ayat (1) hanya dapat didaftar } \\
\text { apabila Indikasi Geografis tersebut telah memperoleh pengakuan dari } \\
\text { pemerintah negaranya dan/atau terdaftar sesuai dengan ketentuan yang } \\
\text { berlaku di negara asalnya. }\end{array}$ \\
\hline 3 & $\begin{array}{c}\text { Pasal } \\
55\end{array}$ & $\begin{array}{l}\text { Indikasi Geografis dapat Pula didaftarkan berdasarkan perjanjian } \\
\text { internasional. } \\
\text { Ketentuan lebih lanjut mengenai pendaftaran Indikasi Geografis dari luar } \\
\text { negeri sebagaimana dimaksud dalam Pasal } 54 \text { diatur dengan Peraturan } \\
\text { Menteri. }\end{array}$ \\
\hline 4 & $\begin{array}{c}\text { Pasal } \\
56\end{array}$ & $\begin{array}{l}\text { Permohonan Indikasi Geografis tidak dapat didaftar jika: } \\
\text { a. Bertentangan dengan ideologi negara, peraturan perundang-undangan, } \\
\text { moralitas, agama, kesusilaan, dan ketertiban umum; } \\
\text { b. Menyesatkan atau memperdaya masyarakat mengenai reputasi, } \\
\text { kualitas, karakteristik, asal sumber, proses pembuatan barang, dan/atau } \\
\text { kegunaannya; dan } \\
\text { c. Merupakan nama yang telah digunakan sebagai varietas tanaman dan } \\
\text { digunakan bagi varietas tanaman yang sejenis, kecuali ada } \\
\text { penambahan padanan kata yang menunjukkan faktor indikasi geografis } \\
\text { yang sejenis. } \\
\text { Permohonan Indikasi Geografis ditolak jika: } \\
\text { a. Dokumen Deskripsi Indikasi Geografis tidak dapat dibuktikan } \\
\text { kebenarannya; dan/atau } \\
\text { b. Memiliki persamaan pada keseluruhannya dengan Indikasi Geografis } \\
\text { yang sudah terdaftar. }\end{array}$ \\
\hline 5 & $\begin{array}{c}\text { Pasal } \\
57\end{array}$ & $\begin{array}{l}\text { Terhadap penolakan sebagaimana dimaksud dalam Pasal } 56 \text { ayat (2) } \\
\text { dapat dimintakan banding kepada Komisi Banding Merek. } \\
\text { Ketentuan mengenai banding sebagaimana dimaksud dalam Pasal } 28 \\
\text { sampai dengan Pasal } 32 \text { berlaku secara mutatis mutandis bagi permintaan } \\
\text { banding sebagaimana dimaksud pada ayat (1). }\end{array}$ \\
\hline 6 & $\begin{array}{c}\text { Pasal } \\
58\end{array}$ & $\begin{array}{l}\text { Pemeriksaan substantif Indikasi Geografis dilakukan oleh Tim Ahli Indikasi } \\
\text { Geografis. } \\
\text { Ketentuan mengenai pemeriksaan substantif Merek sebagaimana dimaksud } \\
\text { dalam Pasal } 23 \text { sampai dengan Pasal } 26 \text { berlaku secara mutatis mutandis }\end{array}$ \\
\hline
\end{tabular}

Focus Group Discution Mengenai Pemahaman Perubahan Aturan Hukum Indikasi Geografis

Bagi Masyarakat Pelestari Padi Pandanwangi Cianjur (MP3C)

Sebagai Pemegang Hak Indikasi Geografis Terdaftar 


\begin{tabular}{|c|c|c|c|}
\hline & & (7) & $\begin{array}{l}\text { hasil penghapusan sebagaimana dimaksud pada ayat (5) keputusan } \\
\text { tersebut diumumkan dalam Berita Resmi Indikasi Geografis. } \\
\text { Pengumuman sebagaimana dimaksud pada ayat (6) harus menyatakan } \\
\text { penghapusan Indikasi Geografis dan berakhirnya hak atas pemakaian } \\
\text { Indikasi Geografis oleh para Pemakai Indikasi Geografis. } \\
\text { Keberatan terhadap penghapusan Indikasi Geografis sebagaimana } \\
\text { dimaksud pada ayat (5) dapat diajukan kepada Pengadilan Niaga paling } \\
\text { lama } 3 \text { (tiga) bulan terhitung sejak diterimanya keputusan penghapusan } \\
\text { tersebut. }\end{array}$ \\
\hline 11 & & \multicolumn{2}{|r|}{$\begin{array}{l}\text { Indikasi asal dilindungi tanpa melalui kewajiban pendaftaran atau secara } \\
\text { deklaratif sebagai tanda yang menunjukkan asal suatu barang dan/atau jasa } \\
\text { yang benar dan dipakai dalam perdagangan. }\end{array}$} \\
\hline 12 & & \multicolumn{2}{|r|}{$\begin{array}{l}\text { Indikasi asal merupakan ciri asal barang dan/atau jasa yang tidak secara } \\
\text { langsung terkait dengan faktor alam. }\end{array}$} \\
\hline 13 & & \multicolumn{2}{|r|}{$\begin{array}{l}\text { Ketentuan lebih lanjut mengenai indikasi asal sebagaimana dimaksud dalam Pasal } \\
63 \text { dan Pasal } 64 \text { diatur dengan Peraturan Menteri. }\end{array}$} \\
\hline 14 & & \multicolumn{2}{|r|}{$\begin{array}{l}\text { Pelanggaran atas Indikasi Geografis mencakup: } \\
\text { (1) Pemakaian Indikasi Geografis, baik secara langsung maupun tidak langsung } \\
\text { atas barang dan/atau produk yang tidak memenuhi Dokumen Deskripsi } \\
\text { Indikasi Geografis; } \\
\text { (2) Pemakaian suatu tanda Indikasi Geografis, baik secara langsung maupun } \\
\text { tidak langsung atas barang dan/atau produk yang dilindungi atau tidak } \\
\text { dilindungi dengan maksud untuk: } \\
\text { a. Menunjukkan bahwa barang dan/atau produk tersebut sebanding } \\
\text { kualitasnya dengan barang dan/atau produk yang dilindungi oleh } \\
\text { Indikasi Geografis; } \\
\text { b. Mendapatkan keuntungan dari pemakaian tersebut; atau } \\
\text { c. Mendapatkan keuntungan atas reputasi Indikasi Geografis. } \\
\text { (3) Pemakaian Indikasi Geografis yang dapat menyesatkan masyarakat } \\
\text { sehubungan dengan asal-usul geografis barang itu; } \\
\text { (4) Pemakaian Indikasi Geografis oleh bukan Pemakai Indikasi Geografis } \\
\text { terdaftar; } \\
\text { (5) Peniruan atau penyalahgunaan yang dapat menyesatkan sehubungan } \\
\text { dengan asal tempat barang dan/atau produk atau kualitas barang } \\
\text { dan/atau produk yang terdapat pada: } \\
\text { a. Pembungkus atau kemasan; } \\
\text { b. Keterangan dalam iklan; } \\
\text { c. Keterangan dalam dokumen mengenai barang dan/atau produk } \\
\text { tersebut; atau } \\
\text { d. Informasi yang dapat menyesatkan mengenai asal-usulnya dalam suatu } \\
\text { kemasan. } \\
\text { (6) Tndakan lainnya yang dapat menyesatkan masyarakat luas mengenai } \\
\text { kebenaran asal barang dan/atau produk tersebut. }\end{array}$} \\
\hline 15 & & (1) & $\begin{array}{l}\text { Terhadap pelanggaran sebagaimana dimaksud dalam Pasal } 66 \text { dapat } \\
\text { diajukan gugatan. } \\
\text { Gugatan sebagaimana dimaksud pada ayat (1) dapat dilakukan oleh: } \\
\text { a. Setiap produsen yang berhak menggunakan Indikasi Geografis; } \\
\text { dan/atau } \\
\text { b. Lembaga yang mewakili masyarakat di kawasan geografis tertentu dan } \\
\text { yang diberi kewenangan untuk itu. }\end{array}$ \\
\hline 16 & & (1) & $\begin{array}{l}\text { Dalam hal sebelum atau pada saat dimohonkan pendaftaran sebagai } \\
\text { Indikasi Geografis, suatu tanda dipakai dengan iktikad baik oleh pihak lain } \\
\text { yang tidak berhak mendaftar menurut ketentuan sebagaimana dimaksud } \\
\text { dalam Pasal } 53 \text { ayat (3), pihak yang beriktikad baik tersebut tetap dapat } \\
\text { menggunakan tanda tersebut untuk jangka waktu } 2 \text { (dua) tahun terhitung } \\
\text { sejak tanda tersebut terdaftar sebagai Indikasi Geografis. } \\
\text { Dalam hal tanda sebagaimana dimaksud pada ayat ( } 1 \text { ) telah terdaftar } \\
\text { sebagai Merek, Menteri membatalkan dan mencoret pendaftaran Merek }\end{array}$ \\
\hline
\end{tabular}

Focus Group Discution Mengenai Pemahaman Perubahan Aturan Hukum Indikasi Geografis

Bagi Masyarakat Pelestari Padi Pandanwangi Cianjur (MP3C)

Sebagai Pemegang Hak Indikasi Geografis Terdaftar 


\begin{tabular}{|c|c|c|c|}
\hline & & $\begin{array}{l}\text { (4) } \\
\text { (5) }\end{array}$ & $\begin{array}{l}\text { tersebut untuk seluruh atau sebagian jenis barang yang sama setelah jangka } \\
\text { waktu } 2 \text { (dua) tahun terhitung sejak tanda tersebut terdaftar sebagai } \\
\text { Indikasi Geografis. } \\
\text { Pembatalan dan pencoretan pendaftaran Merek sebagaimana dimaksud } \\
\text { pada ayat (2) diberitahukan secara tertulis kepada pemilik Merek atau } \\
\text { Kuasanya dengan menyebutkan alasannya. } \\
\text { Pembatalan dan pencoretan pendaftaran Merek sebagaimana dimaksud } \\
\text { pada ayat (2) dicatat dan diumumkan dalam Berita Resmi Merek. } \\
\text { Pembatalan dan pencoretan pendaftaran Merek sebagaimana dimaksud } \\
\text { pada ayat (2) mengakibatkan berakhirnya pelindungan hukum atas Merek } \\
\text { tersebut untuk seluruh atau sebagian jenis barang yang sama. } \\
\text { Keberatan terhadap pembatalan dan pencoretan sebagaimana dimaksud } \\
\text { pada ayat (2) dapat diajukan kepada Pengadilan Niaga. } \\
\text { Terhadap putusan Pengadilan Niaga sebagaimana dimaksud pada ayat (6) } \\
\text { dapat diajukan kasasi. }\end{array}$ \\
\hline 17 & $\begin{array}{c}\text { Pasal } \\
69\end{array}$ & (1) & $\begin{array}{l}\text { Pemegang Hak atas Indikasi Geografis dapat mengajukan gugatan } \\
\text { terhadap Pemakai Indikasi Geografis yang tanpa hak berupa permohonan } \\
\text { ganti rugi dan penghentian penggunaan serta pemusnahan label Indikasi } \\
\text { Geografis yang digunakan secara tanpa hak. } \\
\text { Untuk mencegah kerugian yang lebih besar pada pihak yang haknya } \\
\text { dilanggar, hakim dapat memerintahkan pelanggar untuk menghentikan } \\
\text { kegiatan pembuatan, perbanyakan, serta memerintahkan pemusnahan label } \\
\text { Indikasi Geografis yang digunakan secara tanpa hak. }\end{array}$ \\
\hline 18 & & $\begin{array}{l}\text { (1) } \\
\text { (2) }\end{array}$ & $\begin{array}{l}\text { Pembinaan Indikasi Geografis dilakukan oleh pemerintah pusat dan/atau } \\
\text { pemerintah daerah sesuai dengan kewenangannya. } \\
\text { Pembinaan sebagaimana dimaksud pada ayat (1) meliputi: } \\
\text { a. Persiapan untuk pemenuhan persyaratan Permohonan Indikasi } \\
\text { b. Peografis; } \\
\text { c. Permohonan pendaftaran Indikasi Geografis; } \\
\text { d. Sosialisasi dan pemahaman atas pelindungan Indikasi Geografis; } \\
\text { e. Pemetaan dan inventarisasi potensi produk Indikasi Geografis; } \\
\text { f. Pelatihan dan pendampingan; } \\
\text { g. Pemantauan, evaluasi, dan pembinaan; } \\
\text { h. Pelindungan hukum; dan } \\
\text { b. Fasilitasi pengembangan, pengolahan, dan pemasaran barang } \\
\text { dan/atau produk Indikasi Geografis. }\end{array}$ \\
\hline 19 & & $\begin{array}{l}\text { (1) } \\
\text { (2) } \\
\text { (3) }\end{array}$ & $\begin{array}{l}\text { Pengawasan Indikasi Geografis dilakukan oleh pemerintah pusat dan } \\
\text { pemerintah daerah sesuai dengan kewenangannya. } \\
\text { Pengawasan sebagaimana dimaksud pada ayat ( } 1 \text { ) dapat pula dilakukan } \\
\text { oleh masyarakat. } \\
\text { Pengawasan sebagaimana dimaksud pada ayat ( } 1 \text { ) dan ayat (2) dilakukan } \\
\text { untuk: } \\
\text { a. Menjamin tetap adanya reputasi, kualitas, dan karakteristik yang } \\
\text { b. Menjadi dasar diterbitkannya Indikasi Geografis; dan } \\
\text { Hasil pengawasan sebagaimana dimaksud pada ayat (2) disampaikan } \\
\text { kepada pemegang hak Indikasi Geografis dan/atau Menteri. } \\
\text { Ketentuan lebih lanjut mengenai pengawasan sebagaimana dimaksud pada } \\
\text { ayat (1) sampai dengan ayat (4) diatur dalam Peraturan Menteri. }\end{array}$ \\
\hline
\end{tabular}

Dari uraian di atas, menunjukkan pengaturan Indikasi Geografis pengaturan Indikasi Geografis menurut Undang-Undang Nomor 15 menurut Undang-Undang Nomor 20 tahun 2001 tentang Merek, yang Tahun 2016 tentang Merek dan juga di atur dalam Peraturan Indikasi Geografis lebih Pemerintah Republik Indonesia komprehensif dibandingkan Nomor 51 Tahun 2007 Tentang 
Indikasi Geografis. Ada beberapa perubahan terhadap pengaturan Indikasi Geografis yang perlu diperhatikan, diantaranya:

a. Menurut Undang-Undang Nomor 20 Tahun 2016 tentang Merek dan Indikasi Geografis pemohon Indikasi Geografis diperbolehkan dari Pemerintah Daerah Provinsi atau Kabupaten/Kota, Jika menurut Undang-Undang Nomor 15 tahun 2001 tentang Merek tidak ada pengaturannya;

b. Menurut Undang-Undang Nomor 20 Tahun 2016 tentang Merek dan Indikasi Geografis pemohon Indikasi Geografis memberikan kewenangan kepada Pemerintah Pusat dan/atau Pemerintah Daerah dalam melakukan pembinaan dan pengawasan Indikasi Geografis, Jika menurut Undang-Undang Nomor 15 tahun 2001 tentang Merek tidak ada pengaturannya.

Selanjutnya, mengenai ketentuan pidana ada perbedaan antara Undang-Undang Nomor 15 tahun 2001 tentang Merek dengan Undang-Undang Nomor 20 Tahun 2016 tentang Merek dan Indikasi Geografis pemohon Indikasi Geografis, yaitu:

Tabel 1.4

Perbedaan Ketentuan Pidana Menurut Undang-Undang Nomor 15 tahun 2001 tentang Merek dan UndangUndang Nomor 20 Tahun 2016 tentang Merek dan Indikasi Geografis

\begin{tabular}{|c|c|c|}
\hline No & $\begin{array}{c}\text { Undang-Undang } \\
\text { Nomor } 15 \text { tahun } 2001 \text { tentang Merek }\end{array}$ & $\begin{array}{c}\text { Undang-Undang } \\
\text { Nomor } 20 \text { Tahun } 2016 \text { tentang Merek dan } \\
\text { Indikasi Geografis pemohon Indikasi } \\
\text { Geografis }\end{array}$ \\
\hline 1 & 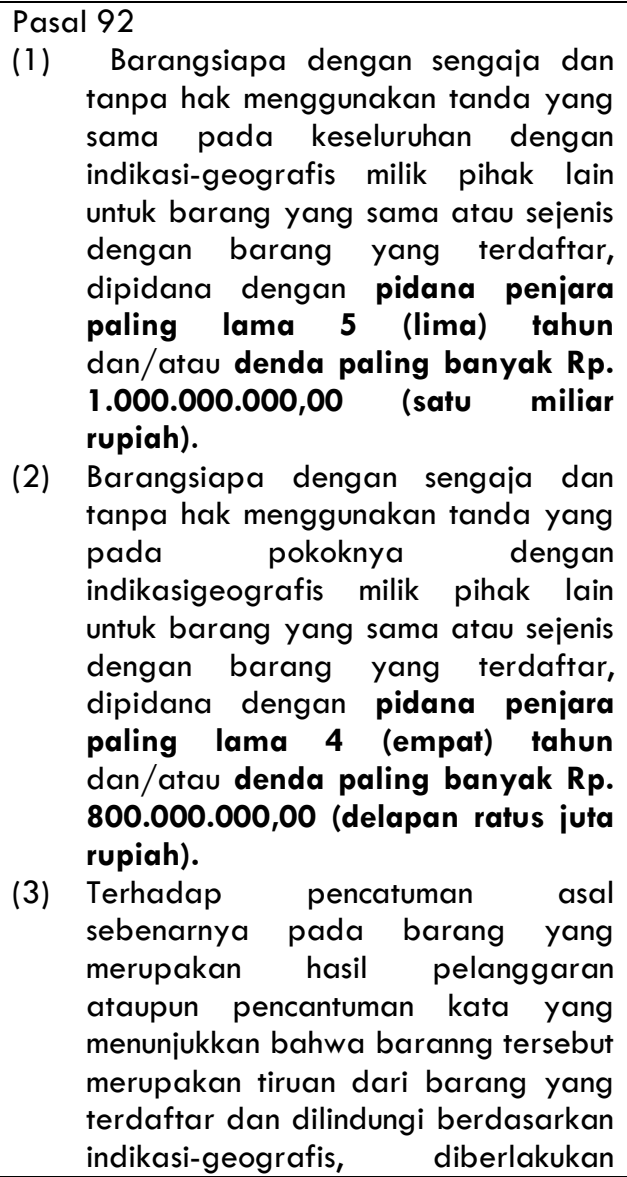 & $\begin{array}{l}\text { Pasal } 101 \\
\text { (1) Setiap Orang yang dengan tanpa hak } \\
\text { menggunakan tanda yang mempunyai } \\
\text { persamaan pada keseluruhan dengan } \\
\text { Indikasi Geografis milik pihak lain untuk } \\
\text { barang dan/atau produk yang sama } \\
\text { atau sejenis dengan barang dan/atau } \\
\text { produk yang terdaftar, dipidana } \\
\text { dengan pidana penjara paling lama } 4 \\
\text { (empat) tahun dan/atau denda paling } \\
\text { banyak Rp. } 2.000 .000 .000,00 \text { (dua } \\
\text { miliar rupiah). } \\
\text { (2) Setiap Orang yang dengan tanpa hak } \\
\text { menggunakan tanda yang mempunyai } \\
\text { persamaan pada pokoknya dengan } \\
\text { Indikasi Geografis milik pihak lain untuk } \\
\text { barang dan/atau produk yang sama } \\
\text { atau sejenis dengan barang dan/atau } \\
\text { produk yang terdaftar, dipidana } \\
\text { dengan pidana penjara paling lama } 4 \\
\text { (empat) tahun dan/atau denda paling } \\
\text { banyak Rp. 2.000.000.000,00 (dua } \\
\text { miliar rupiah). }\end{array}$ \\
\hline
\end{tabular}




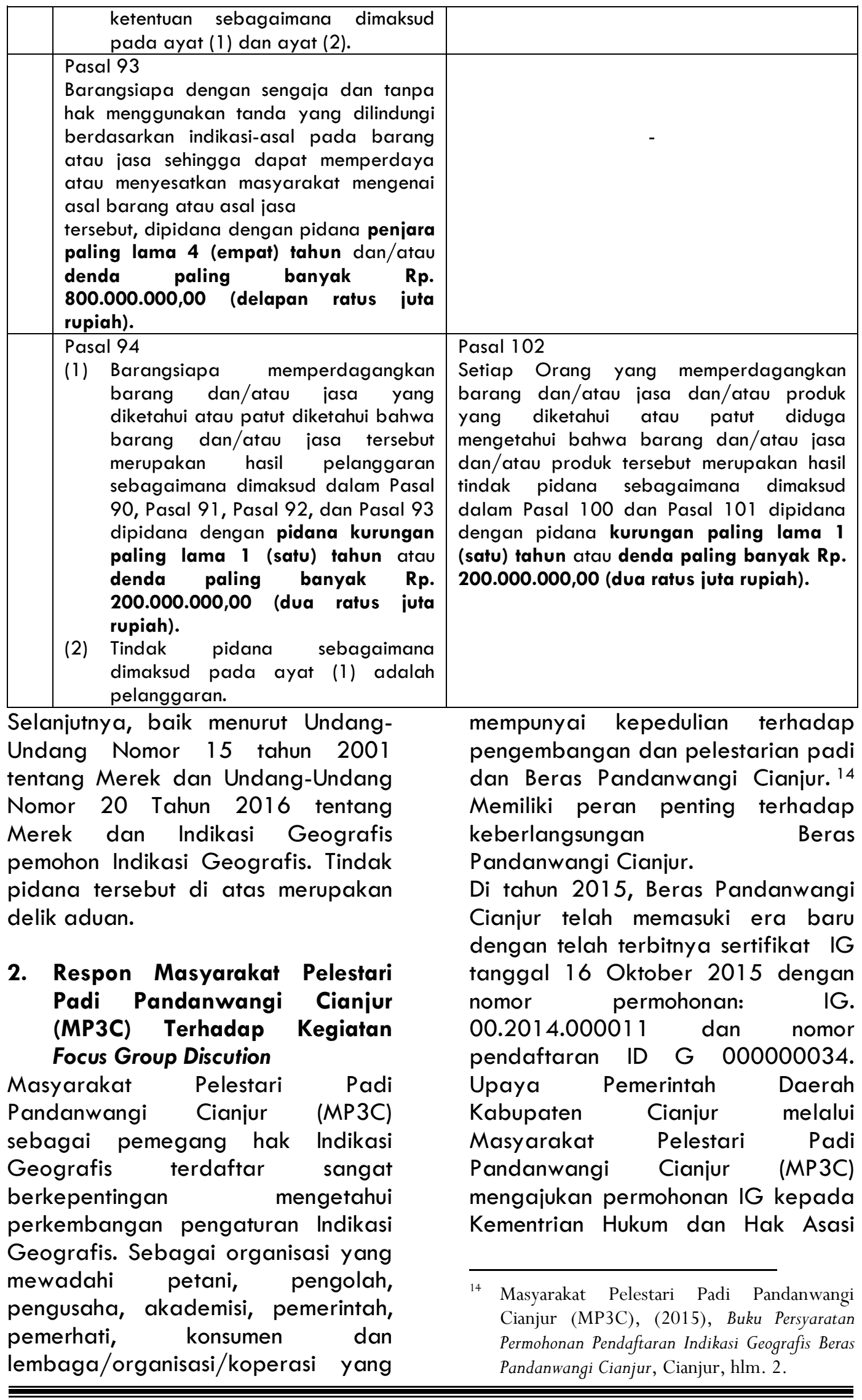


Manusia Republik Indonesia. MP3C selaku yang mewakili permohonan IG sesuai Pasal 56 ayat (2) UndangUndang Republik Indonesia Nomor 15 Tahun 2001 tentang Merek.

Gambar. 2.1.

Sumber: http://www.dgip.go.id/

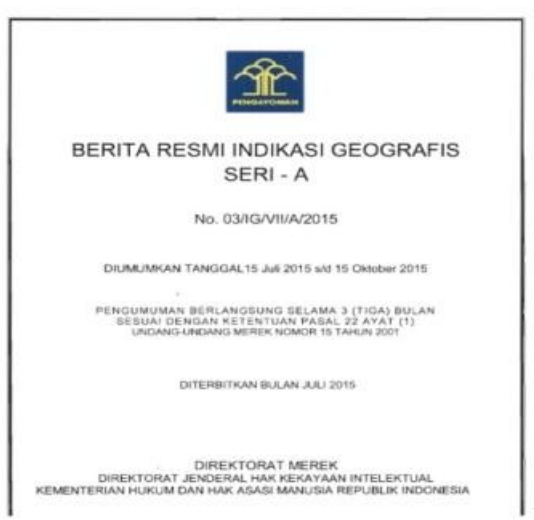

Gambar. 2.2.

Sumber: http://www.dgip.go.id/

INDIKASI GEOGRAFIS BRM 03/IG/VII/A/2015 DIUMUMKAN TGL 15 Juli 2015 s/d 15 Oktober 2015
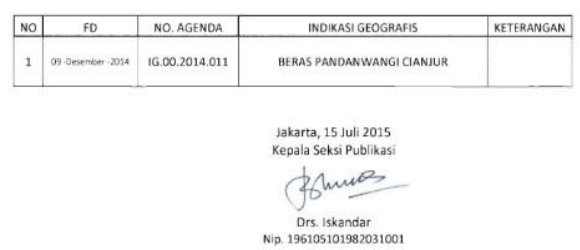

Gambar. 2.3.

Sumber: http://www.dgip.go.id/

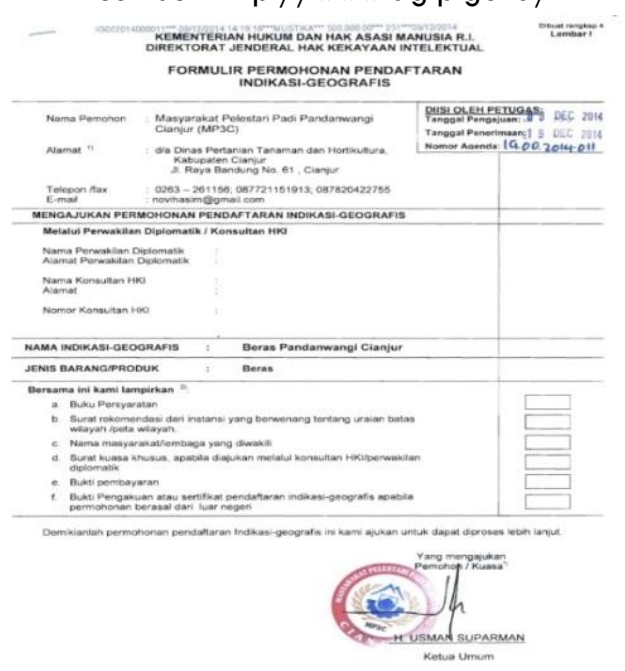

Gambar 2.4.

Sumber: http://www.dgip.go.id/
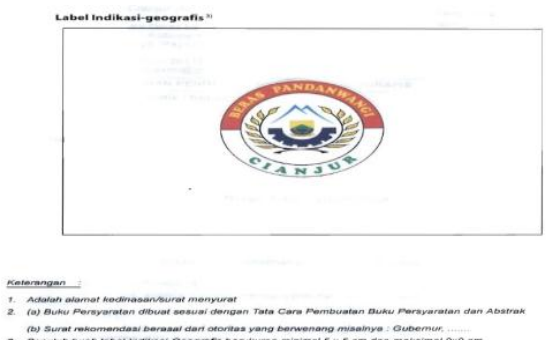

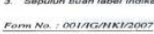

Yang perlu diperhatikan, Beras Pandanwangi Cianjur mendapatkan sertifikat Indikasi Geografis menggunakan pengaturan UndangUndang Republik Indonesia Nomor 15 Tahun 2001 tentang Merek. Saat ini pengaturan Indikasi Geografis menggunakan Undang-Undang Nomor 20 Tahun 2016 tentang Merek dan Indikasi Geografis. Dengan demikian keberlakuan Indikasi Geografis Beras Pandanwangi Cianjur menggunakan aturan yang berlaku.

MP3C harus dapat memastikan bahwa Indikasi Geografis tidak sebagai "proses instrumental" atau percobaan. ${ }^{15}$ Karena, pendaftaran Beras Pandanwangi Cianjur untuk memperoleh sertifikat Indikasi Geografis bertujuan untuk dapat menciptakan perdagangan beras yang sehat, memberikan perlindungan kepada produsen dan konsumen, dan pada akhirnya dapat meningkatkan kesejahteraan petani padi Pandanwangi Cianjur. ${ }^{16}$

Perwakilan MP3C dalam mengikuti focus group discution mengapresiasi

15 Dedi Mulyadi dan M. Rendi Aridhayandi, Putusan Mahkamah Konstitusi tentang Pemilu Serentak Dihubungkan Dengan Pencegahan Korupsi Politik, Jurnal Hukum Mimbar Justitia Volume. 1 Nomor. 2, 2015, hlm. 538.

16 Masyarakat Pelestari Padi Pandanwangi Cianjur (MP3C), (2015), Buku Persyaratan..., Op.Cit, hlm. i. 
dalam pemahaman pengaturan Indikasi Geografis yang berlaku saat ini. Oleh sebab itu, dasar pengaturan sangat penting untuk menjadi acuan didalam melaksanakan amanah UU, yaitu sebagai pemegang hak Indikasi Geografis Terdaftar.

\section{PENUTUP}

1. Kesimpulan

Berdasarkan uraian di atas, maka penulis dapat menarik kesimpulan sebagai berikut:

a. Materi focus group discution mengenai pemahaman perubahan aturan hukum Indikasi Geografis meliputi beberapa aturan Indikasi Geografis di Indonseia perspektif sejarah, perbedaan pengaturan Indikasi Geografis, lebih komprehensif adanya pengaturan Indikasi Geografis dengan UndangUndang Nomor 20 Tahun 2016 tentang Merek dan Indikasi Geografis.

b. Respon peserta focus group discution ini antusias terhadap materi mengenai pemahaman perubahan aturan hukum Indikasi Geografis yang disampaikan.

2. Saran

a. Focus group discution harus dilaksanakan secara berkelanjutan, untuk pemahaman bagi pemegang hak Indikasi Geografis Terdaftar, untuk Beras pandanwangi Cianjur yaitu Masyarakat Pelestari Padi Pandanwangi Cianjur (MP3C).

b. Focus group discution tidak hanya meliputi pemegang hak Indikasi Geografis Terdaftar saja, namun juga Pemerintah Daerah. Hal ini penting untuk tindak lanjut dari focus group discution menjadi Penyuluhan Hukum.

\section{UCAPAN TERIMA KASIH}

Penulis ucapkan banyak terima kasih kepada Rektor Universitas Suryakancana, Dekan Fakultas Hukum Universitas Suryakancana atas segala support yang diberikan, dan tak lupa kepada Pihak Masyarakat Pelestari Padi pandanwangi Cianjur (MP3C) atas focus group discution pada bulan September 2017.

\section{DAFTAR PUSTAKA}

\section{A. Buku}

Henny Nuraeny, (2011), Tindak Pidana Perdagangan Orang Kebijakan Hukum Pidana dan Pencegahannya, Jakarta, Sinar Grafika.

Jill McKeough, Andrew Stewart, Philip Griffith, (2004), Intellectual Property in Australia, edisi ke-3, Sdyney, Butterworths.

Lilik Mulyadi, (2007), Pembalikan Beban Pembuktian Tindak Pidana Korupsi, Alumni, Bandung.

Masyarakat Pelestari Padi Pandanwangi Cianjur (MP3C), (2015), Buku Persyaratan Permohonan Pendaftaran Indikasi Geografis Beras Pandanwangi Cianjur, Cianjur.

Rahmi Jened, (2015), Hukum Merek (Dalam Era Global \& Integrasi Ekonomi), Jakarta, Kencana.

T. Subarsyah Sumadikara, (2010), Penegakan Hukum (Sebuah Pendekatan Politik Hukum dan Politik Kriminal), TT, Kencana Utama. 
B. Peraturan Undangan

Undang-Undang Dasar 1945.

Undang-Undang Nomor 14 tahun 1997 tentang Merek.

Undang-Undang Nomor 15 Tahun 2001 tentang Merek.

Undang-Undang Nomor 20 Tahun 2016 tentang Merek dan Indikasi Geografis.

Peraturan Pemerintah Republik Indonesia Nomor 51 Tahun 2007 Tentang Indikasi Geografis.

C. Jurnal

Ahmad Hunaeni Zulkarnaen, Penyuluhan Tentang Tata Cara Membuat Peraturan Perusahaan Di PT. Pelangi Warna Kreasi Bandung, Journal Of Empowerment Volume. 1, Nomor. 1, 2017.

Anita Kamilah dan M. Rendi Aridhayandi, Kajian Terhadap Penyelesaian Sengketa Pembagian Harta Warisan Atas Tanah Akibat Tidak Dilaksanakannya Wasiat Oleh Ahli Waris Dihubungkan Dengan Buku II Kitab UndangUndang Hukum Perdata Tentang Benda (Van Zaken), Jurnal Wawasan Hukum Volume. 32, Nomor. 1, 2015.

Cucu Solihah, dan Aji Mulyana, Pembayaran Zakat dan Pajak di Negara Hukum Pancasila, Syiar Hukum, Volume. 15, Nomor. 1, 2017.
Mahkamah Konstitusi tentang Pemilu Serentak Dihubungkan Dengan Pencegahan Korupsi Politik, Jurnal Hukum Mimbar Justitia Volume. 1, Nomor. 2, 2015.

Dwidia Priyatno dan M. Rendi Aridhayandi, Resensi Buku (Book Review) Satiipto Rahardjo-llmu Hukum, Jurnal Hukum Mimbar Justitia Volume. 2 Nomor. 2, 2016.

Henny Nuraeny, Penyuluhan Hukum Mengenai Undang-Undang Nomor 21 Tahun 2007 Tentang Pemberantasan Tindak Pidana Perdagangan Orang Bagi Guru Bimbingan Konseling Dan Siswa/Siswi SMK/SMA/MA SeKabupaten Cianjur, Journal Of Empowerment Volume. 1, Nomor. 1, 2017.

M. Rendi Aridhayandi, Resensi Buku (Book Review) Soediman Kartohadiprodio, Kumpulan Karangan, Jakarta: PT Pembangunan, 1965, Jurnal Hukum Mimbar Justitia Volume. 3, Nomor. 1, 2017.

Trini Handayani, Pencegahan Permainan "Starter" Melalui Pendekatan Personal Safety Skill Pada Murid Sekolah Dasar, Journal Of Empowerment Volume. 1, Nomor. 1, 2017.

Dedi Mulyadi dan M. $\begin{array}{r}\text { Rendi } \\ \text { Putusan }\end{array}$ 